\title{
North Central Branch of the Renaissance Society
}

The 1979 Conference of the Branch was held at the University of Michigan (Ann Arbor) on October 19-20. The theme was "Humanism, Piety, and the Arts in the Renaissance." The local committee, chaired by Professor Charles Trinkaus (History) presented an excellent program which attracted delegates from at least ten institutions in the U.S.A. and four in Canada. A generous grant from the Earhart Foundation of Ann Arbor, Michigan, helped to make this North Central (Great Lakes) Conference possible.

At the banquet, Russell Fraser, Director of the Medieval and Renaissance Colloquium, University of Michigan, spoke on "Shakespeare and the Humanists."

The other papers were grouped in four sessions.

\section{Session I}

David E. Crawford, The University of Michigan.

"Humanism and Piety in Renaissance Music and Its Modern Recordings"

Margorie O'Rourke Boyle, Pontifical Institute of Mediaeval Studies.

"Erasmus on Christ and Pagan Learning: The Antibarbari"

John W. O'Malley, S.J., Weston School of Theology.

"Grammar and Rhetoric in the Spirituality of Erasmus"

\section{Session II}

Oscar Büdel, The University of Michigan.

"A me consegnaro il tempo bruno: Self-reflection in Michelangelo's

Night Sonnets"

Jane Couchman, Glendon College of York University.

"Remy Belleau's Eclogues sacrees prises du Cantique des Cantiques de Salomon"

Claudio Guillen, Harvard University.

"Codes and Choices in Don Quixote"

\section{Session III}

Barbara Dodge, York University

"Early Dantean Influences on Tuscan Frescoes of the Inferno" 
Samuel Y. Edgerton, Jr., Boston University.

"Icons of Justice: Art in the Service of Criminal Prosecution in the Renaissance"

R. Ward Bissell, The University of Michigan. "Caravaggio and the Renaissance"

\section{Session IV}

C.A. Patrides, The University of Michigan.

"Spenser: The Contours of Allegorical Theology"

Roland M. Frye, The University of Pennsylvania.

"Paysages Moralises in Shakespeare and the Paintings of his Age"

Balachandra Rajan, The University of Western Ontario.

"Milton, Humanism and the Concept of Piety"

At the business meeting it was agreed that the 1980 Conference would be held on November 14:15 at the University of Guelph, with C. Stuart Hunter as Chairman. The 1981 Conference will be held at the University of Akron, with D'Orsay Pearson as Chairman.

The duties of the Secretary of the Branch were transferred from A. Kent Hieatt and J.A.B. Somerset (both of Western Ontario) to C. Stuart Hunter and Murdo MacKinnon (both of the Department of English, University of Guelph, Guelph, Ontario). 